\title{
SIMULASI PENENTUAN KEBUTUHAN BANGUNAN TERHADAP SISTEM PROTEKSI PETIR EKSTERNAL PADA GEDUNG ICT CENTER
}

\author{
Nadia Noviarty Sriyanto, Agung Warsito, Abdul Syakur \\ Departemen Teknik Elektro, Universitas Diponegoro \\ Jl. Prof. Sudharto, SH, Kampus UNDIP Tembalang, Semarang 50275, Indonesia \\ Email : nadianoviarty@yahoo.co.id
}

\begin{abstract}
Abstrak
Indonesia yang terletak didaerah khatulistiwa dan beriklim tropis dengan tingkat kelembapan yang tinggi, memiliki tingkat hari guruh yang tinggi pula. Benda atau bangunan berstruktur tinggi memiliki potensi lebih besar terhadap sambaran petir. Oleh karena itu, suatu bangunan memerlukan suatu sistem proteksi petir yang sesuai untuk melindungi dari kerusakan yang bisa disebabkan oleh sambaran petir tersebut seperti pada gedung ICT Center. Dengan menggunakan standar PUIPP juga IEC 1024-1-1, dapat diketahui tingkat kebutuhan sistem proteksi petir pada gedung tersebut dan area yang terlindung dapat dilihat dengan beberapa metode penempatan terminasi udara yaitu sudut lindung dan rolling sphere. Hasil penelitian ini berupa analisa perbandingan area proteksi berdasarkan teori sesuai dengan beberapa contoh kasus yang digunakan. Diharapkan hasil penelitian ini bisa menjadi referensi untuk memenuhi kebutuhan proteksi petir eksternal pada suatu gedung.
\end{abstract}

Kata kunci: Sistem Proteksi Petir Eksternal, Ruang Proteksi

\begin{abstract}
Indonesia, the country which is located in equator region with tropical climate and high humidity, has a high possibility of having thunderstorm days too. An object with approximate heights or skyscraper buildings have a high chance of taking lightning strike. The buildings need a suitable lightning protection system to prevent damages from lightning strike such as ICT Center. The rate of the needs for lightning protection system on the building can be calculated using PUIPP and IEC 1024-1-1 standards and the used methods to determining position of air termination are protective angle and rolling sphere. This research, therefore, hoped to give result for future references to satisfy the needs for external lighting protection on buildings.
\end{abstract}

Keywords: External Lightning Protection System, Protection Zone

\section{Pendahuluan}

Letak geografis Indonesia yang terletak di daerah khatulistiwa dengan iklim tropis dan tingkat kelembapan yang tinggi menyebabkan tingginya tingkat hari guruh dan mempunyai kerapatan sambaran petir yang besar jika dibanding dengan negara lain. Di Indonesia terutama kota Semarang berdasarkan data BMG Indonesia tahun 1999, memiliki 148 hari guruh rata-rata pertahun. Tingginya hari guruh tersebut dapat menimbulkan bahaya pada bangunan serta peralatan yang disebabkan oleh sambaran petir baik itu sambaran langsung maupun tak langsung.

Kebutuhan suatu bangunan terhadap sistem proteksi petir relatif berbeda. Menurut Dr. Abdul Syakur, ST, MT dan Ir. Yuningtyastuti, MT dalam jurnal transmisi dengan judul "Sistem Proteksi Penangkal Petir Pada Gedung Widya Puraya" dijelaskan bahwa bangunan yang terletak di daerah dengan karakteristik perbukitan memiliki potensi lebih tinggi mengalami gangguan atau kerusakan akibat petir. Jadi dapat diketahui bahwa letak bangunan yang memiliki kontur tanah berbeda memiliki tingkat kebutuhan akan proteksi petir yang berbeda pula terlebih jika bangunan lain yang lebih tinggi di sekitarnya. Dengan kata lain, kondisi tanah kota Semarang yang berbukit akan mempengaruhi tingkat kebutuhan sistem proteksi petir pada bangunan di daerah tersebut. Berdasarkan hal tersebut dalam penelitian ini penulis melaksanakan penelitian untuk mengetahui tingkat kebutuhan sistem proteksi petir pada suatu bangunan berdasarkan letak bangunan dengan menggunakan standar Peraturan Umum Instalasi Penangkal Petir (PUIPP) dan International Electrotechnical Commision (IEC) 1024-1-1 juga untuk mengetahui daerah proteksi yang dihasilkan sistem proteksi petir pada bangunan tersebut dengan menggunakan metode bola bergulir dan sudut lindung. Sampel data gedung yang digunakan diambil dari data gedung ICT Center Universitas Diponegoro Semarang.

\section{Metode}

Metode dalam penyusunan penelitian meliputi beberapa tahap yaitu studi pustaka dengan mempelajari literatur 
yang berhubungan dengan penelitian. Kemudian pengumpulan data. Data dikumpulkan dan diperoleh dari survey secara langsung, buku, jurnal, maupun literatur yang berkaitan dengan penelitian. Data yang diperoleh disimulasikan dalam bentuk gambar dengan bantuan software SketchUp dan untuk menampilkan hasil kebutuhan bangunan terhadap sistem proteksi petir juga perhitungan ruang proteksi bangunan digunakan software MatLab. Hasil perhitungan kebutuhan sistem proteksi petir juga gambar ruang proteksi yang didapat, dianalisa dan ditarik kesimpulan

\subsection{Kebutuhan Bangunan akan Sistem Proteksi Petir}

Suatu instalasi proteksi petir harus dapat melindungi semua bagian dari suatu bangunan terhadap bahaya dan kerusakan akibat sambaran petir. Berikut ini merupakan cara penentuan besarnya kebutuhan bangunan akan proteksi petir menggunakan standar Peraturan Umum Instalasi Penangkal Petir (PUIPP) dan International Electrotechnical Commision (IEC) 1024-1-1.

\subsubsection{Peraturan Umum Instalasi Penangkal Petir (PUIPP)}

Berdasarkan PUIPP besarnya kebutuhan tersebut ditentukan berdasarkan penjumlahan indeks-indeks tertentu yang mewakili keadaan bangunan di suatu lokasi diantaranya indeks A mengenai bahaya berdasarkan jenis bangunan, indeks B mengenai bahaya berdasarkan konstruksi bangunan, indeks C mengenai bahaya berdasarkan tinggi bangunan, indeks $\mathrm{D}$ mengenai bahaya berdasarkan situasi bangunan dan indeks $\mathrm{E}$ mengenai bahaya berdasarkan hari guruh. Berdasarkan indeksindeks tersebut, maka nilai perkiraan bahaya sambaran petir $(\mathrm{R})$ dapat dituliskan sebagai:

$\mathrm{R}=\mathrm{A}+\mathrm{B}+\mathrm{C}+\mathrm{D}+\mathrm{E}$

Tabel 1. Indeks A: Bahaya berdasarkan jenis bangunan

\begin{tabular}{ll}
\hline Penggunaan dan Isi & Indeks A \\
\hline $\begin{array}{l}\text { Bangunan biasa yang tak perlu diamankan baik bangunan } \\
\text { maupun isinya }\end{array}$ & -10 \\
$\begin{array}{l}\text { Bangunan dan isinya jarang digunakan misalnya dangau di } \\
\text { tengah sawah atau ladang, menara atau tiang dari metal }\end{array}$ & 0 \\
$\begin{array}{l}\text { Bangunan yang berisi peralatan sehari-hari atau tempat } \\
\text { tinggal misalnya rumah tinggal, industri kecil, dan stasiun }\end{array}$ & 1 \\
$\begin{array}{l}\text { kereta api } \\
\text { Bangunan atau isinya cukup penting misalnya menara air, }\end{array}$ & 2 \\
toko barang-barang berharga dan kantor pemerintah \\
$\begin{array}{l}\text { Bangunan yang berisi banyak sekali orang, misalnya } \\
\text { bioskop, sarana ibadah, sekolah, dan monumen bersejarah }\end{array}$ \\
$\begin{array}{l}\text { yang penting } \\
\text { Instalasi gas, minyak atau bensin, dan rumah sakit }\end{array}$ \\
$\begin{array}{l}\text { Bangunan yang mudah meledak dan dapat menimbulkan } \\
\text { bahaya yang tidak terkendali bagi sekitarnya misalnya } \\
\text { instalasi nuklir }\end{array}$ & 5 \\
\hline
\end{tabular}

Berdasarkan hasil penjumlahan indeks-indeks tersebut, dapat diketahui nilai perkiraan bahaya sambaran petir seperti pada tabel 6 sehingga dapat diketahui tingkat kebutuhan sistem proteksi petir pada bangunan tersebut.

Tabel 2. Indeks B: Bahaya berdasarkan konstruksi bangunan.

\begin{tabular}{ll}
\hline Konstruksi Bangunan & Indeks B \\
\hline $\begin{array}{l}\text { Seluruh bangunan terbuat dari logam dan mudah } \\
\text { menyalurkan listrik }\end{array}$ & 0 \\
$\begin{array}{l}\text { Bangunan dengan konstruksi beton bertulang atau } \\
\text { rangka besi dengan atap logam }\end{array}$ & 1 \\
$\begin{array}{l}\text { Bangunan dengan konstruksi beton bertulang, } \\
\text { kerangka besi dan atap bukan logam }\end{array}$ & 2 \\
Bangunan kayu dengan atap bukan logam & 3 \\
\hline
\end{tabular}

Tabel 3. Indeks C: Bahaya berdasarkan tinggi bangunan

\begin{tabular}{ll}
\hline Tinggi bangunan $(\boldsymbol{m})$ & Indeks $\mathbf{C}$ \\
\hline 0 sampai dengan 6 & 0 \\
7 sampai dengan 12 & 2 \\
13 sampai dengan 17 & 3 \\
18 sampai dengan 25 & 4 \\
26 sampai dengan 35 & 5 \\
36 sampai dengan 50 & 6 \\
51 sampai dengan 70 & 7 \\
71 sampai dengan 100 & 8 \\
101 sampai dengan 140 & 9 \\
141 sampai dengan 200 & 10 \\
\hline
\end{tabular}

Tabel 4. Indeks D: Bahaya berdasarkan situasi bangunan

\begin{tabular}{ll}
\hline Situasi Bangunan & Indeks D \\
\hline Di tanah datar pada semua ketinggian & 0 \\
Di kaki bukit sampai $3 / 4$ tinggi bukit atau di pegunungan & 1 \\
sampai 1000 meter & \\
Di puncak gunung atau pegunungan yang lebih dari & 2 \\
1000 meter & \\
\hline
\end{tabular}

Tabel 5. Indeks E: Bahaya berdasarkan hari guruh.

\begin{tabular}{ll}
\hline Hari Guruh per tahun & Indeks E \\
\hline 2 & 0 \\
4 & 1 \\
8 & 2 \\
16 & 3 \\
32 & 4 \\
64 & 5 \\
128 & 6 \\
256 & 7 \\
\hline
\end{tabular}

Tabel 6. Perkiraan bahaya sambaran petir berdasarkan PUIPP.

\begin{tabular}{lll}
\hline $\mathbf{R}$ & Perkiraan Bahaya & Pengamanan \\
\hline Dibawah 11 & Diabaikan & Tidak perlu \\
11 & Kecil & Tidak perlu \\
12 & Sedang & Dianjurkan \\
13 & Agak Besar & Dianjurkan \\
14 & Besar & Sangat dianjurkan \\
Lebih dari 14 & Sangat Besar & Sangat perlu \\
\hline
\end{tabular}

\subsubsection{Pemilihan Tingkat Proteksi Berdasarkan IEC 1024- 1-1}

Berdasarkan standar IEC 1024-1-1, pemilihan tingkat proteksi yang memadai untuk suatu sistem proteksi petir 
didasarkan pada frekuensi sambaran petir langsung setempat yang diperkirakan ke struktur yang diproteksi dan frekuensi sambaran petir tahunan setempat yang diperbolehkan. Kerapatan kilat petir ke tanah atau kerapatan sambaran petir ke tanah rata-rata tahunan di daerah tempat suatu struktur berada dinyatakan sebagai:

$\mathrm{Ng}=0,04 . \mathrm{T}^{1,25}$ sambaran $/ \mathrm{km}^{2} /$ tahun

Area cakupan disekitar bangunan yang memiliki resiko terkena sambaran petir langsung seperti yang ditunjukan pada gambar 1 dapat dinyatakan sebagai berikut:

$\mathrm{Ae}=\mathrm{ab}+6 \mathrm{~h}(\mathrm{a}+\mathrm{b})+9 \pi \mathrm{h}^{2}$

Kondisi tanah yang berbeda seperti pada gambar 2 menyebabkan perbedaan nilai Ae yang berbeda juga. Untuk daerah yang berbukit, nilai Ae dapat dinyatakan sebagai berikut:

$A e=a b+6 h_{e}(a+b)+9 \pi h_{e}^{2}$

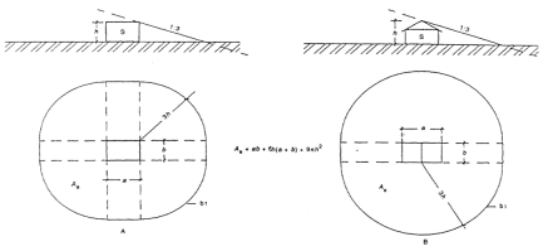

Gambar 1. Area cakupan sebuah bangunan pada tanah datar

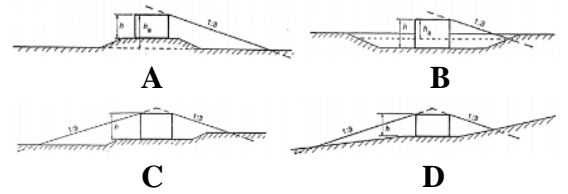

Gambar 2. Area cakupan sebuah bangunan di daerah berbukit.

Nilai frekuensi sambaran petir langsung disekitar gedung dapat dinyatakan sebagai:

$\mathrm{Nd}=\mathrm{Ng}$. Ae. $10^{-6}$ sambaran/tahun

Pengambilan keputusan perlu atau tidaknya memasang sistem proteksi petir pada bangunan berdasarkan perhitungan $\mathrm{Nd}$ dan $\mathrm{Nc}$ dilakukan sebagai berikut:

- $\quad$ Jika $\mathrm{Nd} \leq \mathrm{Nc}$ tidak perlu sistem proteksi petir

- Jika $\mathrm{Nd}>\mathrm{Nc}$ diperlukan sistem proteksi petir dengan efisiensi:

$\mathrm{E} \geq 1-\frac{\mathrm{Nc}}{\mathrm{Nd}}$

dengan tingkat proteksi sesuai tabel 7 .

Tabel 7. Efisiensi Sistem Proteksi Petir.

\begin{tabular}{ll}
\hline Tingkat Proteksi & Efisiensi SPP \\
\hline I & 0,98 \\
II & 0,95 \\
III & 0,90 \\
IV & 0,80 \\
\hline
\end{tabular}

\subsection{Sistem Proteksi Petir Eksternal}

Sistem proteksi petir eksternal adalah sistem penangkap petir yang instalasi dan alat-alatnya diletakkan diluar struktur, dengan perlindungan langsung terhadap sambaran petir terdiri dari :

1. Penangkap petir / terminasi udara (air termination) / finial.

2. Penghantar penyalur (down conductor)

3. Pentanahan (grounding)

\subsection{Terminasi udara (air termination) / Penangkap Petir}

Terminasi udara / penangkap petir adalah bagian sistem proteksi petir eksternal yang dikhususkan untuk menangkap sambaran petir, berupa elektroda logam yang dipasang secara tegak maupun mendatar.

\subsubsection{Jenis Terminasi Udara}

Berdasarkan jenisnya, penangkap petir dibagi menjadi dua yaitu penangkap petir konvensional dan non konvensional.

\section{Terminasi Udara Konvensional}

Jenis sistem terminasi udara konvensional dipengaruhi oleh keadaan atap dari gedung yang akan diamankan. Untuk bangunan dengan atap runcing atau selisih tinggi bumbungan dan lisplang lebih dari satu meter, maka dapat menggunakan sistem Franklin yaitu penempatan satu atau lebih finial batang konduktor dengan bagian ujung runcing secara tegak terhadap bangunan seperti pada gambar 3 (a). Sedangkan untuk bangunan dengan atap datar atau bangunan yang memiliki selisih tinggi antara bumbungan dan lisplang kurang dari satu meter maka dapat menggunakan sistem Faraday yaitu penempatan finial batang konduktor secara mendatar yang saling terhubung mengelilingi atap bangunan seperti yang terlihat pada gambar 3 .

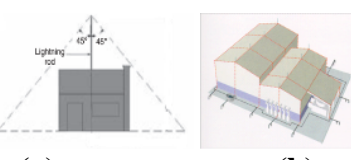

(a)

(b)

Gambar 3. Jenis sistem terminasi udara konvensional

(a) Sistem terminasi udara Franklin

(b) Sistem terminasi udara Faraday

\section{Terminasi Udara Non-konvensional}

Metode ini pertama kali dipatenkan oleh Gusta P Carpart tahun 1931. Sebelumnya seorang ilmuwan Hungaria, Szillard tahun 1941 pernah melontarkan gagasan untuk menambahkan bahan radioaktif pada franklin rod guna meningkatkan tarikan pada sambaran petir. Metode ini 
terdiri atas franklin rod dengan bahan radioaktif sebagai penghasil ion yang dihubungkan ke pentanahan melalui penghantar khusus.

Sistem terminasi udara Early Streamer Emission (ESE) adalah metode terbaru dalam penyelesaian masalah kerusakan yang disebabkan oleh petir yang dilengkapi dengan sistem franklin rod. ESE adalah terminal udara radioaktif non konvensional, tetapi banyak negara telah melarang hal ini karena sumber radioaktif yang posisinya dekat dengan bagian atas terminal membahayakan kesehatan.

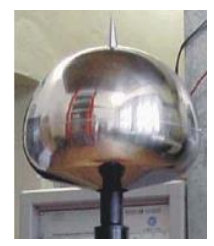

\section{Gambar 4. Terminasi Udara Non-konvensional}

\subsubsection{Metode Penempatan Terminasi Udara}

Ada beberapa metode yang digunakan untuk menentukan penempatan terminasi udara dan untuk mengetahui daerah proteksi diantaranya yaitu

a. Metode Bola Bergulir (Rolling Sphere Method)

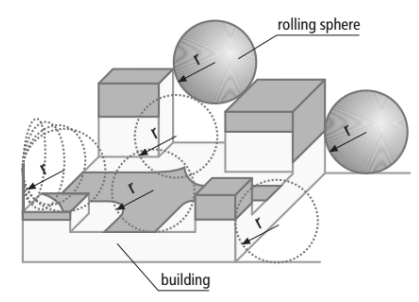

Gambar 5. Metode bola bergulir (Rolling Sphere)

Metode bola bergulir terlihat seolah-olah ada suatu bola dengan radius $\mathrm{R}$ yang bergulir di atas tanah, sekeliling bangunan dan di atas bangunan ke segala arah hingga bertemu dengan tanah atau bangunan yang berhubungan dengan permukaan bumi yang mampu bekerja sebagai penghantar. Nilai $\mathrm{R}$ didapat dari jarak sambaran akhir antara petir dengan objek. Titik sentuh bola bergulir pada struktur adalah titik yang dapat disambar petir dan pada titik tersebut harus diproteksi oleh konduktor terminasi udara seperti yang ditunjukan pada gambar 5. Semua petir yang berjarak $\mathrm{R}$ dari ujung terminasi udara akan mempunyai kesempatan yang sama untuk menyambar bangunan. Besarnya $\mathrm{R}$ berhubungan dengan besar arus petir yang dinyatakan dengan persamaan Whitehead: $\mathrm{R}=8 \mathrm{I}^{0,65}$

Berikut merupakan standar metode penempatan terminasi udara berdasarkan tingkat proteksinya:
Tabel 8. Penempatan terminasi udara sesuai dengan tingkat proteksi

\begin{tabular}{llllll}
\hline $\begin{array}{l}\text { Level } \\
\text { proteksi }\end{array}$ & $\begin{array}{l}\text { Bola } \\
\mathrm{r}(\mathrm{m})\end{array}$ & bergulir & \multicolumn{5}{l}{ Sudut lindung $\left(^{\circ}\right)$} \\
\cline { 3 - 6 } & & $20 \mathrm{~m}$ & $30 \mathrm{~m}$ & $45 \mathrm{~m}$ & $60 \mathrm{~m}$ \\
\hline I & 20 & 25 & $*$ & $*$ & $*$ \\
II & 30 & 35 & 25 & $*$ & $*$ \\
III & 45 & 45 & 35 & 25 & $*$ \\
IV & 60 & 55 & 45 & 35 & 25 \\
\hline
\end{tabular}

b. Metode Sudut Pelindung (Protective Angle Method)

Metode sudut lindung ini membuat daerah lindung sesuai dengan konduktor tegak, dimana daerah yang diproteksi berada didalam kerucut dengan sudut proteksi sesuai dengan tingkat proteksi. Pada gambar 6 , nilai $h$ menunjukan tinggi terminasi udara. Sedangkan besar sudut pada terminasi udara dapat diketahui seperti pada tabel 8 .

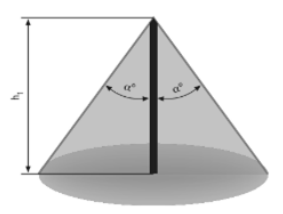

Gambar 6. Metode Sudut lindung

\section{Hasil dan Analisa}

3.1. Kebutuhan Sistem Proteksi Petir Gedung ICT Center berdasarkan PUIPP

Indeks kebutuhan sistem proteksi petir pada gedung berdasarkan PUIPP merupakan hasil penjumlahan nilainilai pada indeks tersebut yang ditunjukan pada persamaan (2.1). Sedangkan data indeks kebutuhan gedung ICT Center terhadap sistem proteksi petir ditunjukan pada tabel 3.9.

$$
\begin{aligned}
& R=A+B+C+D+E \\
& R=3+2+5+1+6 \\
& R=17
\end{aligned}
$$

Berdasarkan tabel 6 dapat diketahui bahwa Gedung ICT Center memiliki perkiraan bahaya yang sangat besar dan sangat memerlukan sistem proteksi petir.

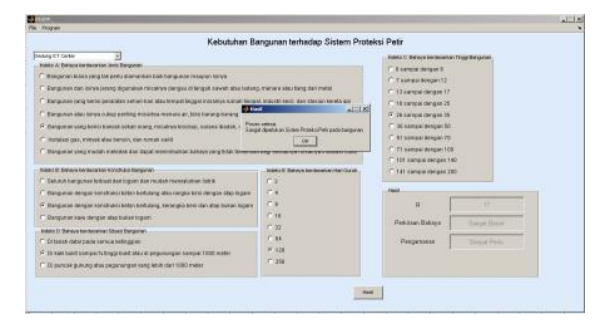

Gambar 7. Screenshot tampilan program PUIPP pada Matlab R2008a 


\subsection{Kebutuhan Sistem Proteksi Petir Gedung ICT Center berdasarkan IEC 1024-1-1}

Kebutuhan sistem proteksi petir berdasarkan IEC 1024-11 pada suatu bangunan dapat diketahui dengan menggunakan data bangunan juga ditentukan berdasarkan frekuensi sambaran petir langsung setempat yang diperkirakan ke struktur yang diproteksi dan frekuensi sambaran petir tahunan setempat yang diperbolehkan. Langkah-langkah perhitungannya adalah sebagai berikut:

1. Kerapatan sambaran petir rata-rata tahunan di daerah

$$
\begin{aligned}
& \mathrm{Ng}=0,04 \times \mathrm{T}^{1,25} \\
& \mathrm{Ng}=0,04 \times 148^{1,25} \\
& \mathrm{Ng}=20,648 / \mathrm{km}^{2} / \text { tahun }
\end{aligned}
$$

2. Area disekitar bangunan yang memiliki resiko terkena sambaran petir langsung

$$
\begin{aligned}
& A e=a b+6 h(a+b)+9 \pi h^{2} \\
& A e=47,8 \times 26,92+6 \times 31(47,8+26,92)+9 \pi \times 31^{2} \\
& A e=1286,78+186(74,72)+9 \pi \times 961 \\
& A e=42.356,33 \mathrm{~m}^{2}
\end{aligned}
$$

3. Nilai frekuensi sambaran petir langsung disekitar gedung

$$
\begin{aligned}
& \mathrm{Nd}=\mathrm{Ng} \cdot \text { Ae. } 10^{-6} \\
& \mathrm{Nd}=20,648 \times 42.356,33 \times 10^{-6} \\
& \mathrm{Nd}=0,8746 / \text { tahun }
\end{aligned}
$$

Untuk menentukan perlu atau tidaknya sistem proteksi petir pada bangunan, digunakan perhitungan $\mathrm{Nd}$ dan Nc. Jika $\mathrm{Nd}>\mathrm{Nc}$ maka bangunan memerlukan sistem proteksi petir.

$$
\begin{aligned}
& \mathrm{Nc}=0,1 \\
& \mathrm{Nd}=0,8746 \\
& \mathrm{Nd}>\mathrm{Nc} \\
& 0,8746>0,1
\end{aligned}
$$

4. Efisiensi sistem proteksi petir

$$
\begin{aligned}
& \mathrm{E} \geq 1-\frac{\mathrm{Nc}}{\mathrm{Nd}} \\
& \mathrm{E} \geq 1-\frac{0,1}{0,8746} \\
& E \geq 0,88566
\end{aligned}
$$

Berdasarkan nilai efisiensi tersebut, dapat diketahui bahwa Gedung ICT Center masuk ke tingkat proteksi IV.

Tabel 9. Hasil perhitungan kebutuhan sistem proteksi petir sesuai dengan IEC 1024-1-1

\begin{tabular}{cc}
\hline Parameter & Hasil perhitungan \\
\hline $\mathrm{Ng}$ & 20,648 \\
$\mathrm{Ae}$ & $42.356,33$ \\
$\mathrm{Nd}$ & 0,8746 \\
$\mathrm{Nc}$ & 0,1 \\
$\mathrm{E}$ & 0,88566 \\
Tingkat Proteksi & Tingkat IV \\
\hline
\end{tabular}

Dengan menggunakan fitur GUI pada software MatLab R2008a, perhitungan tersebut dapat diketahui sesuai dengan gambar berikut:

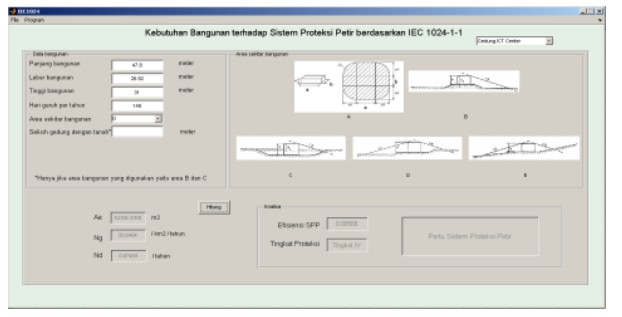

Gambar 8. Screenshot tampilan program IEC 1024-1-1 pada MatLab R2008a

\subsection{Penentuan Besar Ruang Proteksi Gedung ICT Center}

Berdasarkan tabel 9 dapat diketahui bahwa besar kebutuhan Sistem Proteksi Petir gedung ICT Center adalah tingkat IV dengan efisiensi 0,88566. Dari hasil perhitungan ini maka dapat dilakukan perbandingan untuk mengetahui besar ruang proteksi dengan menggunakan dua metode perancangan SPP eksternal sistem terminasi udara yaitu: metode sudut lindung dan metode bola bergulir (rolling sphere).

\section{a. Metode Sudut Lindung}

Gedung ICT Center memiliki panjang $[a]=47,80$ meter; lebar $[b]=26,92$ meter dan tinggi bangunan $[\mathrm{h}]=31$ meter. Panjang terminasi udara $[\ell]$ diperoleh dari data dengan nilai sebesar $4,70 \mathrm{~m}$. Tinggi dudukan terminasi udara adalah 1,25 m. Maka tinggi SPP eksternal terisolasi dari permukaan tanah (bidang referensi) dapat dihitung sebagai berikut:

$$
\begin{aligned}
\mathrm{h}_{\mathrm{SPP}}=\mathrm{h}+\ell+ & \text { dudukan } \\
& =31+4,7+1,25 \\
& =36,95 \mathrm{~m}
\end{aligned}
$$

Dari tabel 8 dapat diketahui besar sudut proteksi untuk gedung ICT Center dengan level proteksi tingkat IV adalah sebesar $45^{\circ}$. Dengan mengetahui besar sudut proteksi dan tinggi SPP eksternal terisolasi maka jarak terjauh yang masih terlindungi oleh satu penangkap petir (R) pada gedung ICT Center dapat dihitung sebagai berikut:

$$
\begin{aligned}
\mathrm{R} & =\tan 45 \cdot \mathrm{h}_{\mathrm{SPP}} \\
& =1 \times 36,95 \\
& =36,95 \mathrm{~m}
\end{aligned}
$$

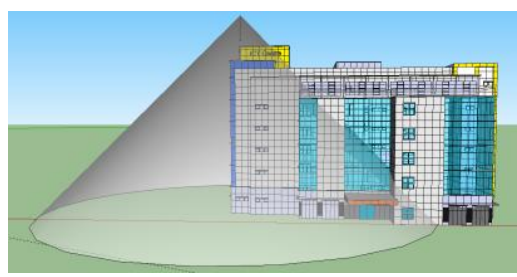

Gambar 9. Tampak depan ruang proteksi gedung ICT Center dengan metode sudut lindung

Berdasarkan data gedung dan gambar 9 dapat dilihat bahwa penerapan metode sudut lindung pada gedung ICT 
Center dengan bangunan atap berbentuk datar, jumlah terminasi udara 1 buah, tinggi SPP eksternal terisolasi terminasi udara dari bidang referensi sebesar 36,95 meter, besar sudut proteksi $45^{\circ}$ dan radius ruang proteksi 36,95 meter, terlihat bahwa gedung belum sepenuhnya terlindung atau ada bagian gedung berada di luar daerah proteksi sehingga masih membutuhkan adanya peningkatan proteksi SPP eksternal terutama pada bagian atap gedung. Untuk mengatasi hal tersebut maka dapat dilakukan modifikasi dengan cara meninggikan terminasi udara atau menambah jumlah terminasi udara sehingga diperoleh posisi yang tepat untuk memproteksi gedung sehingga seluruh bagian gedung dapat terlindung atau berada dalam ruang proteksi.

\section{b. Metode Rolling Sphere/Bola Bergulir}

Pada metode bola bergulir, ruang proteksi merupakan daerah antara perpotongan permukaan tanah (bidang referensi), tepi bangunan dan keliling bola bergulir. Dari tabel 8 dapat diperoleh jari- jari rolling sphere untuk gedung ICT Center dengan level proteksi IV adalah 60 meter.

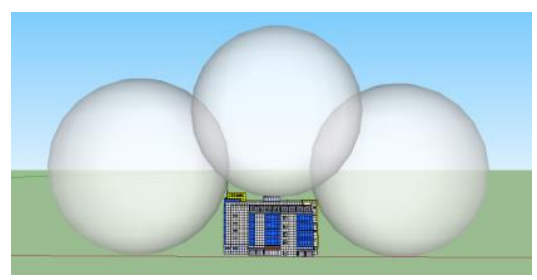

Gambar 10. Tampak depan ruang proteksi gedung ICT Center dengan metode bola bergulir

Berdasarkan data gedung serta gambar 10 dapat dilihat bahwa penerapan metode bola bergulir pada gedung ICT Center dengan bangunan atap berbentuk datar, jumlah terminasi udara 1 buah, tinggi SPP eksternal terisolasi terminasi udara dari bidang referensi sebesar 36,95 meter dan jari- jari rolling sphere sebesar 60 meter terlihat bahwa masih terdapat bagian atap gedung berada dalam bola bergulir sehingga mempunyai kemungkinan besar tersambar petir oleh karena itu perlu adanya peningkatan daerah proteksi yang salah satunya dapat dilakukan dengan cara meninggikan terminasi udara atau menambah jumlah terminasi udara sehingga diperoleh posisi yang tepat untuk memproteksi gedung dan dapat dipastikan gedung tidak tersentuh oleh bola bergulir.

\subsection{Simulasi Kebutuhan Sistem Proteksi Petir Gedung ICT Center}

Pada penelitian ini disimulasikan Gedung ICT Center pada area letak bangunan yang berbeda-beda seperti pada gambar 1 dan 2 dengan satu bangunan disekitarnya yang digambarkan berbentuk seperti Gedung ICT Center namun dengan tinggi yang berbeda yaitu $29 \mathrm{~m}$ (dimisalkan dengan nama Gedung A) dan $37 \mathrm{~m}$ (dimisalkan dengan nama Gedung B). Seperti halnya dengan Gedung ICT Center, harus dihitung kebutuhan sistem proteksi petirnya sesuai dengan IEC 1024-1-1.

\section{a. Untuk bangunan dengan ketinggian 29 m.}

1. Kerapatan sambaran petir rata-rata tahunan di daerah

$$
\begin{aligned}
& \mathrm{Ng}=0,04 \times \mathrm{T}^{1,25} \\
& \mathrm{Ng}=0,04 \times 148^{1,25} \\
& \mathrm{Ng}=20,648 / \mathrm{km}^{2} / \text { tahun }
\end{aligned}
$$

2. Area disekitar bangunan yang memiliki resiko terkena sambaran petir langsung

$$
\begin{aligned}
& \mathrm{Ae}=\mathrm{ab}+6 \mathrm{~h}(\mathrm{a}+\mathrm{b})+9 \pi \mathrm{h}^{2} \\
& \mathrm{Ae}=47,8 \times 26,92+6 \times 29(47,8+26,92)+9 \pi \times 29^{2} \\
& \mathrm{Ae}=1286,78+174(74,72)+9 \pi \times 841 \\
& \mathrm{Ae}=38.066,77 \mathrm{~m}^{2}
\end{aligned}
$$

3. Nilai frekuensi sambaran petir langsung disekitar gedung

$$
\begin{aligned}
& \mathrm{Nd}=\mathrm{Ng} . \text { Ae. } 10^{-6} \\
& \mathrm{Nd}=20,648 \times 38 \cdot 066,77 \times 10^{-6} \\
& \mathrm{Nd}=0,78602 / \text { tahun }
\end{aligned}
$$

4. Efisiensi sistem proteksi petir

$$
\begin{aligned}
& \mathrm{E} \geq 1-\frac{\mathrm{Nc}}{\mathrm{Nd}} \\
& \mathrm{E} \geq 1-\frac{0,1}{0,78602} \\
& E \geq 0,87278
\end{aligned}
$$

Berdasarkan nilai efisiensi tersebut, dapat diketahui bahwa Gedung A masuk ke tingkat proteksi IV.

b. Untuk bangunan dengan ketinggian $37 \mathrm{~m}$.

1. Kerapatan sambaran petir rata-rata tahunan di daerah

$$
\begin{aligned}
& \mathrm{Ng}=0,04 \times \mathrm{T}^{1,25} \\
& \mathrm{Ng}=0,04 \times 148^{1,25} \\
& \mathrm{Ng}=20,648 / \mathrm{km}^{2} / \text { tahun }
\end{aligned}
$$

2. Area disekitar bangunan yang memiliki resiko terkena sambaran petir langsung

$$
\begin{aligned}
& \mathrm{Ae}=\mathrm{ab}+6 \mathrm{~h}(\mathrm{a}+\mathrm{b})+9 \pi \mathrm{h}^{2} \\
& \mathrm{Ae}=47,8 \times 26,92+6 \times 37(47,8+26,92)+9 \pi \times 37^{2} \\
& \mathrm{Ae}=1286,78+222(74,72)+9 \pi \times 1369 \\
& \mathrm{Ae}=56.582,18 \mathrm{~m}^{2}
\end{aligned}
$$

3. Nilai frekuensi sambaran petir langsung disekitar gedung

$$
\begin{aligned}
& \mathrm{Nd}=\mathrm{Ng} . \text { Ae. } 10^{-6} \\
& \mathrm{Nd}=20,648 \times 56 \cdot 582,18 \times 10^{-6} \\
& \mathrm{Nd}=1,1683 / \text { tahun }
\end{aligned}
$$

4. Efisiensi sistem proteksi petir

$$
\begin{aligned}
& \mathrm{E} \geq 1-\frac{\mathrm{Nc}}{\mathrm{Nd}} \\
& \mathrm{E} \geq 1-\frac{0,1}{1,1683} \\
& E \geq 0,91441
\end{aligned}
$$

Berdasarkan nilai efisiensi tersebut, dapat diketahui bahwa Gedung B masuk ke tingkat proteksi III.

Setelah diketahui tingkat proteksi masing-masing gedung seperti pada tabel 10, maka simulasi dapat dilakukan dengan menempatkan gedung $\mathrm{A}$ atau gedung $\mathrm{B}$ disekitar gedung ICT Center dengan jarak \pm 15 meter. 
Tabel 10. Tabel perbandingan hasil perhitungan gedung ICT Center, gedung A dan gedung B

\begin{tabular}{cccc}
\hline \multirow{2}{*}{ Parameter } & \multicolumn{3}{c}{ Hasil perhitungan } \\
\cline { 2 - 4 } & $\begin{array}{c}\text { Gedung A } \\
(\mathbf{2 9 m})\end{array}$ & $\begin{array}{c}\text { ICT Center } \\
(\mathbf{3 1 m})\end{array}$ & $\begin{array}{c}\text { Gedung B } \\
(\mathbf{3 7 m})\end{array}$ \\
\hline $\mathrm{Ng}$ & 20,648 & 20,648 & 20,648 \\
$\mathrm{Ae}$ & $38.066,77$ & $42.356,33$ & $56.582,18$ \\
$\mathrm{Nd}$ & 0,78602 & 0,8746 & 1,1683 \\
$\mathrm{Nc}$ & 0,1 & 0,1 & 0,1 \\
$\mathrm{E}$ & 0,87278 & 0,88566 & 0,91441 \\
Tingkat Proteksi & Tingkat IV & Tingkat IV & Tingkat III \\
\hline
\end{tabular}

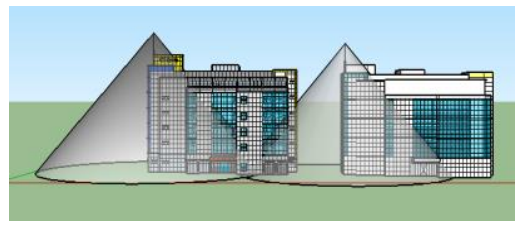

Gambar 11. Tampak depan gedung ICT Center dan gedung A dengan metode sudut lindung pada tanah datar

Pada gambar 11 dan 12 dapat diketahui bahwa sebagian gedung ICT Center masuk dalam ruang proteksi gedung A. Namun pada kedua gedung masih terlihat bagian bangunan yang tidak berada dalam ruang proteksi sudut lindung sehingga masih berpotensi terkena sambaran petir langsung. Untuk mengatasi hal tersebut, dapat dilakukan peningkatan tingkat proteksi dan penambahan jumlah terminasi udara pada atap sehingga semua bagian gedung dapat terlindungi.

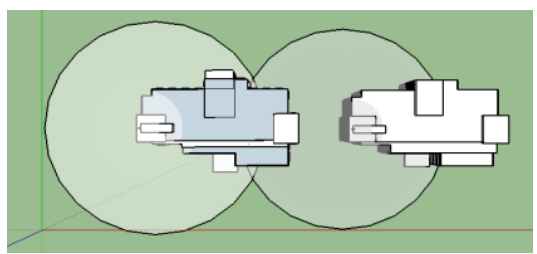

Gambar 12. Tampak atas gedung ICT Center dan gedung A dengan metode sudut lindung pada tanah datar



Gambar 13. Tampak depan gedung ICT Center dan gedung A dengan metode rolling sphere pada tanah datar

Pada gambar 13 dan 14 dapat diketahui bahwa masih terdapat bagian gedung ICT Center dan gedung A yang masih terkena permukaan bola sehingga masih berpotensi terkena sambaran petir langsung. Untuk mengatasi hal tersebut, dapat dilakukan peningkatan tingkat proteksi dan penambahan jumlah terminasi udara pada atap sehingga bola tidak mengenai permukaan gedung dan semua bagian gedung dapat terlindungi.

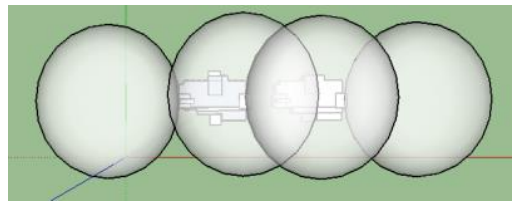

Gambar 14. Tampak atas gedung ICT Center dan gedung A dengan metode rolling sphere pada tanah datar



Gambar 15. Tampak depan gedung ICT Center dan gedung A dengan metode sudut lindung pada tanah $\mathrm{A}$

Pada gambar 15 dan 16 dapat diketahui bahwa ruang proteksi gedung A mengenai gedung ICT Center sehingga sebagian gedung A terlindungi. Selain itu pada kedua gedung masih terlihat bagian bangunan yang tidak berada dalam ruang proteksi sudut lindung sehingga masih berpotensi terkena sambaran petir langsung. Untuk mengatasi hal tersebut, dapat dilakukan peningkatan tingkat proteksi dan penambahan jumlah terminasi udara pada atap sehingga semua bagian gedung dapat terlindungi.

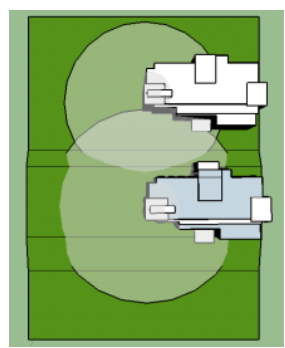

Gambar 16. Tampak atas gedung ICT Center dan gedung A dengan metode sudut lindung pada tanah $\mathrm{A}$

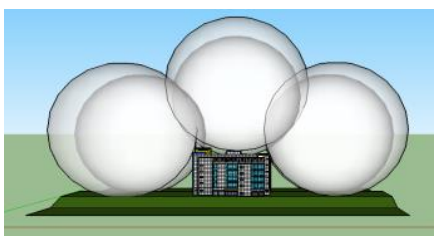

Gambar 17. Tampak depan gedung ICT Center dan gedung A dengan metode rolling sphere pada tanah A

Pada gambar 17 dan 18 dapat diketahui bahwa masih terdapat bagian gedung ICT Center dan gedung A yang masih terkena permukaan bola sehingga masih berpotensi terkena sambaran petir langsung. Untuk mengatasi hal tersebut, dapat dilakukan peningkatan tingkat proteksi dan 
penambahan jumlah terminasi udara pada atap sehingga bola tidak mengenai permukaan gedung dan semua bagian gedung dapat terlindungi.

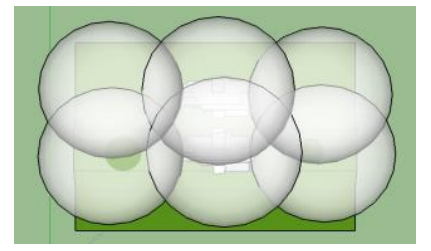

Gambar 18. Tampak atas gedung ICT Center dan gedung A dengan metode rolling sphere pada tanah A

\section{Kesimpulan}

Hasil analisa metode PUIPP dapat diketahui bahwa Gedung ICT Center memiliki perkiraan bahaya yang sangat besar dan sangat memerlukan sistem proteksi petir. Sedangkan dengan menggunakan metode IEC 1024-1-1, Gedung ICT Center masuk ke tingkat proteksi IV dengan nilai efisiensi 0,88566. Pada metode sudut lindung pada Gedung ICT Center, dapat diketahui bahwa gedung belum sepenuhnya terlindung atau ada bagian gedung berada di luar daerah proteksi sehingga masih membutuhkan adanya peningkatan proteksi SPP eksternal terutama pada bagian atap gedung. Sedangkan pada metode bola bergulir pada Gedung ICT Center, dapat diketahui bahwa masih terdapat bagian atap gedung berada dalam bola bergulir sehingga mempunyai kemungkinan besar tersambar petir oleh karena itu perlu adanya peningkatan daerah proteksi. Simulasi pada tanah datar dengan metode sudut lindung pada Gedung ICT Center dengan gedung A dan gedung $\mathrm{B}$, keduanya menunjukan hasil yang sama. Sebagian ruang proteksi gedung A ataupun B pada jarak \pm 15 meter mengenai gedung sehingga sebagian gedung ICT Center terlindungi. Namun pada kedua gedung masih terlihat bagian yang tidak berada dalam ruang proteksi sehingga masih berpotensi terkena sambaran petir. Sedangkan dengan metode rolling sphere masih terdapat bagian gedung yang terkena permukaan bola sehingga berpotensi terkena sambaran petir langsung. Pada simulasi tanah A, dengan metode sudut lindung pada Gedung ICT Center dengan gedung $\mathrm{A}$ dan gedung $\mathrm{B}$, keduanya menunjukan hasil yang sama. Sebagian ruang proteksi gedung ICT Center mengenai gedung A juga gedung B sehingga sebagian gedung tersebut terlindungi. Namun pada kedua gedung masih terlihat bagian yang tidak berada dalam ruang proteksi sehingga masih berpotensi terkena sambaran petir. Sedangkan dengan metode rolling sphere masih terdapat bagian gedung yang terkena permukaan bola sehingga berpotensi terkena sambaran petir langsung.

\section{Referensi}

[1]. “Sistem Proteksi Petir pada Bangunan Gedung”, SNI 03-7015-2004, 2004.

[2]. T. Suhartanto, "Penentuan Kebutuhan Proteksi Petir pada Gedung Teknik Elektro Undip dengan adanya bangunan Menara Base Transceiver Station," Laporan Tugas Akhir, Departemen Teknik Elektro, Universitas Diponegoro, 2007.

[3]. A. Syakur, Yuningtyastuti, "Sistem Proteksi Petir pada Gedung Widya Puraya," Transmisi, vol. 11, no. 1, hal. 35-39, Jun 2006.

[4]. "Peraturan Umum Instalasi Penangkal Petir untuk Bangunan di Indonesia”, 1983.

[5]. Protection of structures against lightning," IEC 1024$1-1,1993$.

[6]. A. D. Hermawan, "Optimalisasi Sistem Penangkal Petir Eksternal Menggunakan Jenis Early Streamer (Study kasus UPT LAGG BPPT)," Laporan Tugas Akhir, Departemen Teknik Elektro, Universitas Indonesia, 2010.

[7]. ERITECH® Lightning Protection Handbook, ERICO, 2009.

[8]. Lightning Protection Guide-3rd updated edition, Dehn International, 2014.

[9]. Blue Print Gedung ICT Center

[10]. "Peresmian Gedung ICT Centre" diakses pada 24 Oktober 2015

[11]. R. H. Golde, "Lightning”. Volume 2. London : Academic Press Inc, 1981.

[12]. C. Bouquegneau, "External lightning protection system," Vernon Cooray, London, United Kingdom: The Institute of Engineering and Technology, 2010, 307-354.

[13]. H. Z. Abidin dan R. Ibrahim, "Conventional and Unconventional Lightning Air Terminals: An Overview," dipresentasikan di Lightning Protection Forum, Selangor, Malaysia, 2004 